\title{
$\beta$-Adrenergic Neuroeffector Abnormalities in the Failing Human Heart Are Produced by Local Rather Than Systemic Mechanisms
}

\author{
Michael R. Bristow, Wayne Minobe, Randy Rasmussen, Patti Larrabee, Lisa Skerl, Jana W. Klein, Frederick L. Anderson, \\ June Murray, Luisa Mestroni, S. V. Karwande, Michael Fowler, ${ }^{\star}$ and Robert Ginsburg* \\ Heart Failure Treatment Program, University of Utah Medical Center, Salt Lake City, Utah 84132; and Cardiology Division, \\ Department of Medicine, Stanford University Hospital, Stanford, California 94305
}

Abstract

In order to investigate the general cause of $\beta$-adrenergic receptor neuroeffector abnormalities in the failing human heart, we measured ventricular myocardial adrenergic receptors, adrenergic neurotransmitters, and $\beta$-adrenergic receptor-effector responses in nonfailing and failing hearts taken from nonfailing organ donors, subjects with endstage biventricular failure due to idiopathic dilated cardiomyopathy (IDC), and subjects with primary pulmonary hypertension (PPH) who exhibited isolated right ventricular failure. Relative to nonfailing PPH left ventricles, failing PPH right ventricles exhibited $(a)$ markedly decreased $\beta_{1}$-adrenergic receptor density, (b) marked depletion of tissue norepinephrine and neuropeptide $Y$, (c) decreased adenylate cyclase stimulation in response to the $\beta$ agonists isoproterenol and zinterol, and $(d)$ decreased adenylate cyclase stimulation in response to $\mathrm{Gpp}(\mathrm{NH}) \mathrm{p}$ and forskolin. These abnormalities were directionally similar to, but generally more pronounced than, corresponding findings in failing IDC right ventricles, whereas values for these parameters in nonfailing left ventricles of PPH subjects were similar to values in the nonfailing left ventricles of organ donors. Additionally, relative to paired nonfailing PPH left ventricles and nonfailing right ventricles from organ donors, failing right ventricles from PPH subjects exhibited decreased adenylate cyclase stimulation by $\mathrm{MnCl}_{2}$.

These data indicate that: (a) Adrenergic neuroeffector abnormalities present in the failing human heart are due to local mechanisms; systemic processes do not produce $\beta$-adrenergic neuroeffector abnormalities. (b) Pressure-overloaded failing right ventricles of PPH subjects exhibit decreased activity of the catalytic subunit of adenylate cyclase, an abnormality not previously described in the failing human heart. (J. Clin. Invest. 1992. 89:803-815.) Key words: adenylate cyclase $\bullet$ adrenergic neurotransmitters $\bullet \boldsymbol{\beta}$-adrenergic receptors $\bullet$ heart failure • pulmonary hypertension

Current address for Drs. Bristow and Ginsburg, Mr. Minobe, and Ms. Skerl: Division of Cardiology, University of Colorado Health Sciences Center, 4200 East Ninth Avenue, Denver, CO 80262.

Address reprint requests to Dr. Bristow.

Received for publication 19 October 1990 and in revised form 10 October 1991.

J. Clin. Invest.

(c) The American Society for Clinical Investigation, Inc.

$0021-9738 / 92 / 03 / 0803 / 13 \$ 2.00$

Volume 89, March 1992, 803-815

\section{Introduction}

Heart failure in humans is accompanied by a complex series of changes in neuroendocrine function. These changes include generalized adrenergic activation $(1,2)$, regional cardiac and renal adrenergic activation (3), increased activity of the reninangiotensin system (4), an increase in vasopressin secretion (5) and counterregulatory activation of vasodilator mechanisms including increased atrial natriuretic factor secretion (6) and an increase in vasodilator prostaglandin production (7). The net result of these adjustments is to increase heart rate, cardiac contractile state, left ventricular end-diastolic volume, and central arterial pressure. These compensatory changes serve to maintain perfusion to organs with autoregulatory control of resistance, mainly brain and heart $(8,9)$. Because vasoconstriction is usually produced by the combined effects of neuroendocrine activation, total cardiac output may actually be compromised by these compensatory mechanisms $(8,9)$. This realization and recent data indicating that treatment with angiotensin-converting enzyme inhibitors exerts a favorable effect on the natural history of heart failure (10) suggest that some, if not most, of the primarily activated compensatory mechanisms may be harmful when chronically expressed.

At the myocardial level numerous changes in the effector systems that interact with the adrenergic nervous system have been described. These include selective $\beta_{1}$-receptor down-regulation (11), uncoupling of $\beta_{2^{-}}$(12) and $\beta_{1^{-}}$(13) adrenergic receptors, and tissue norepinephrine depletion (14-16). Depletion of norepinephrine tissue stores is "paradoxical" inasmuch as cardiac interstitial concentrations of norepinephrine appear to be increased in heart failure $(17,18)$. This paradox appears to be due to a marked abnormality in neuronal norepinephrine uptake in the failing human heart (18-20), which leads to both an increase in synaptic cleft/interstitial concentrations of norepinephrine and a decrease in neuronal norepinephrine stores.

Thus heart failure is accompanied by abnormalities in both systemic and local cardiac neuroendocrine function. It is unclear whether the local changes that occur in the adrenergic neuroeffector pathways are a consequence of systemic processes or whether they are under regional control and may in fact contribute to the systemic abnormalities, such as by providing a substantial contribution to the increased level of circulating norepinephrine present in heart failure (3). One approach to distinguishing between systemic and local causes for altered adrenergic neuroeffector mechanisms in the failing heart is to examine these mechanisms in chambers that exhibit isolated ventricular failure, that is, in situations where one ventricle is failing and the other is not. When such an analysis is 
made, abnormalities that are present in both ventricles can be attributed to systemic or hormonal factors, whereas abnormalities present only in the failing ventricle can be attributed to local or regional regulatory processes.

In the current study we examine isolated right ventricular failure in the setting of primary pulmonary hypertension (PPH), ${ }^{1}$ using human hearts explanted at the time of heart-lung transplantation. In these hearts a comparison of nonfailing left vs. failing right ventricles indicates that the $\beta_{1}$-receptor downregulation, adrenergic neurotransmitter depletion, and abnormalities in adenylate cyclase that accompany endstage heart failure are confined to the failing right ventricle. This indicates that ( $a$ ) $\beta_{1}$-receptor down-regulation is not caused by a systemic process, but rather is under local regulatory control and (b) adrenergic neurotransmitter depletion is also under local control, suggesting that regional adrenergic activation is responsible for $\beta_{1}$-receptor down-regulation in the failing human heart.

\section{Methods}

\section{Tissue procurement}

Human cardiac tissue was procured in cooperation with the Utah or Stanford Cardiac Transplant Programs. Tissue was subdivided as follows:

Nonfailing controls (group A). 12 hearts were obtained from locally procured organ donors with no known cardiac history who had been maintained on no or a minimal amount of dopamine for circulatory support. "Minimal" dopamine exposure was defined as a dose of $<5$ $\mu \mathrm{g} / \mathrm{kg} \cdot \min$ for $\leq 4 \mathrm{~h}$, or $<8 \mu \mathrm{g} / \mathrm{kg} \cdot \min$ for $\leq 1 \mathrm{~h}$ before cardiac excision. 6 of the 12 organ donors had received no dopamine within $48 \mathrm{~h}$ of organ procurement, and for the group as a whole the dopamine dose averaged $0.9 \mu \mathrm{g} / \mathrm{kg} \cdot \min$ for $0.7 \mathrm{~h}$. The age of the donors varied from 5 to $71 \mathrm{yr}$, with a median of $31 \mathrm{yr}$. In these respirator-dependent, braindead kidney donors, the hearts could not be placed because of no available recipient with the proper blood type and/or size match $(n=7)$, donor age $(n=3)$, or mild coronary artery disease with $<50 \%$ stenosis $(n=2)$. In all cases echocardiograms performed as part of the organ donation screening process (21) revealed normal global left ventricular function, defined as a left ventricular shortening fraction of $\geq 25 \%$.

Cardiac excision was performed as previously described (22), after harvest of donated extra-cardiac organs. The heart was then placed in ice-cold oxygenated Tyrode's solution (22) and brought immediately to the laboratory. The time between removal and homogenization was $<\mathbf{3 0} \mathrm{min}$ in all cases.

Biventricular failure (group B). 54 cardiac transplant recipients with idiopathic dilated cardiomyopathy (IDC) and biventricular failure by clinical and catheterization criteria had their hearts removed at the time of transplantation. The excised heart was immediately placed in ice-cold oxygenated Tyrode's solution and transported to the laboratory. The time between removal and homogenization was $<30 \mathrm{~min}$ in all cases. $\beta$-Blocking agents, $\beta$ agonists, or phosphodiesterase inhibitor inotropes had not been given within $5 \mathrm{~d}$ of transplantation to any group B subject, whose ages ranged from 10 to $61 \mathrm{yr}$ (median $43 \mathrm{yr}$ ).

Isolated right ventricular failure (group C). Hearts with isolated right ventricular failure were obtained from 12 patients aged $23-43 \mathrm{yr}$ (median $36 \mathrm{yr}$ ) who underwent heart-lung transplantation for PPH. Hearts removed at the time of transplantation were processed as described above for groups $A$ and $B$. In all cases left ventricular function was normal by echocardiographic criteria or radionuclide data; severe right ventricular failure was evident by catheterization or echocardio-

1. Abbreviations used in this paper: $\mathrm{Gpp}(\mathrm{NH}) \mathrm{p}$, guanylyl imidodiphosphate; ICYP, iodocyanopindolol; IDC, idiopathic dilated cardiomyopathy; NPY, neuropeptide Y; PPH, primary pulmonary hypertension; VIP, vasoactive intestinal peptide. graphic and clinical criteria. No heart-lung recipient had received dopamine, or any other $\beta$ agonist before transplant.

\section{Tissue processing}

5-6-g aliquots of left and right ventricular mid-free wall were trimmed free of epicardial fat and subendocardial fibrosis, minced finely with scissors, and placed in ice-cold $10 \mathrm{mM}$ Tris, $1 \mathrm{mM}$ EGTA buffer, $\mathrm{pH} 8$, for preparation of crude membranes suitable for radioligand binding. Membranes were prepared as previously described by extraction of contractile proteins with $0.5 \mathrm{M} \mathrm{KCl}$ and repeatedly washing a $50,000-g$ pellet. This method results in a two- to threefold enrichment of $\beta$ adrenergic receptors and membranes markers compared to the initial homogenate $(11,23)$.

In hearts removed from five subjects with PPH a 10-g aliquot of left and right ventricular free wall was excised as above, and membranes were prepared as previously described for "method A" (22). This technique yields a $50,000-g$ pellet that has not been exposed to high salt concentrations. The supernatants of the first $50,000-g$ pellet were spun at $158,000 \mathrm{~g}$ for $1 \mathrm{~h}$, and the resulting "light density" pellet was resuspended in $50 \mathrm{mM}$ Tris, $250 \mathrm{mM}$ sucrose, $1 \mathrm{mM}$ EGTA, pH 7.5, and frozen at $-70^{\circ} \mathrm{C}$ until use. The washed and resuspended $50,000-g$ pellet was considered to be a "heavy density" membrane fraction and was stored as per the light density membranes.

2-g aliquots from the left and right ventricular free wall were removed and immediately minced and placed in ice-cold $250 \mathrm{mM}$ sucrose, $5 \mathrm{mM}$ Tris, $1 \mathrm{mM}$ EGTA buffer, $\mathrm{pH} 7.5$, to make a particulate fraction suitable for adenylate-cyclase assays (22). A $1,085-g$ pellet of ventricular myocardium was washed twice in the above buffer and resuspended to a final concentration of $8-12 \mathrm{mg} / \mathrm{ml}$ and frozen at $-70^{\circ}$ until further use. This preparation differs from the crude membrane fraction used for radioligand binding by having less vigorous homogenization and no exposure to $0.5 \mathrm{M} \mathrm{KCl}$ and being a lower speed pellet.

Aliquots of left and right ventricular free wall suitable for tissue catecholamine and neuropeptide Y (NPY) measurements were immediately frozen at $-70^{\circ}$. For catecholamine measurements $100-200 \mathrm{mg}$ of tissue was homogenized within 2 wk of procurement in $0.4 \mathrm{~N} \mathrm{HCl}$ containing $5 \mathrm{mM}$ glutathione and using $1 \mathrm{ml} / 100 \mathrm{mg}$ of tissue. Homogenization was accomplished by three consecutive 5-s bursts with a Polytron (Brinkmann Instruments, Inc., Westbury, NY) and then 20 passes through a motor-driven mortar and pestle. This material was centrifuged at $1,500 \mathrm{~g}$ for $15 \mathrm{~min}$, and the supernatant was removed and frozen at $-70^{\circ}$ until used for radioenzymatic assays. For NPY measurements, 25-75-mg aliquots of tissue were thawed, minced, and boiled in $0.01 \mathrm{~N} \mathrm{HCl}$ for $10 \mathrm{~min}$, and homogenized.

All measurements were performed on every available preparation. Exhaustion of preparations and tissue samples in some cases led to the experimental $n$ being less than the number of hearts procured for a particular group.

\section{Receptor measurements by radioligand binding}

$\beta$-Adrenergic receptor density and antagonist affinity were measured by $\left[{ }^{125} \mathrm{I}\right]$ iodocyanopindolol (ICYP) binding in crude membranes as previously described (24). Assays were performed within 2 mo of tissue procurement, and membranes were stored at concentrations of 5-10 $\mathrm{mg} / \mathrm{ml}$ in $250 \mathrm{mM}$ sucrose, $50 \mathrm{mM}$ Tris, $1 \mathrm{mM}$ EGTA buffer, $\mathrm{pH} 7.5$, at $-70^{\circ}$ until used. Under these conditions receptor density is maintained for at least $3 \mathrm{mo}(11,23)$. The percent $\beta_{1}$ and $\beta_{2}$ receptors was determined by computer modeling of ICYP-betaxolol (11) or ICYPCGP 20712A (25) competition curves using previously described methods. For CGP 20712A, which at concentrations $>10^{-5} \mathrm{M}$ can displace ICYP binding beyond that by $3 \mu \mathrm{M}$ propranolol or $1 \mathrm{mM}$ isoproterenol, the bottom of the ICYP-CGP 20712A competition curve was taken as the simultaneously measured displacement by $3 \mu \mathrm{M}$ (-) propranolol. Agonist binding affinity was measured by isoproterenol-ICYP competition curves using either 50 or $100 \mathrm{pM}$ ICYP to maintain the radioligand concentration at 3-5 $\times K_{\mathrm{D}}$. 18-point isoproterenol competition curves between concentrations of $10^{-10}$ and 
$10^{-3} \mathrm{M}$ were measured under steady-state ( $2 \mathrm{~h}$ of incubation) conditions using $(-)$ isoproterenol. Competition curve slope, $\mathrm{IC}_{50}$, the percentage of receptors in a high $\left(K_{\mathrm{H}}\right)$ or low $\left(K_{\mathrm{L}}\right)$ affinity state, and $K_{\mathrm{H}}$ and $K_{\mathrm{L}}$ were determined by computer modeling using previously described methods (11).

$\alpha_{1}$-Adrenergic receptor density and antagonist affinity was measured by [ $\left.{ }^{125} I\right]$ IBE-2254 binding, according to previously described methods (26).

\section{Adenylate cyclase measurements}

Adenylate cyclase response to hormones, sodium fluoride, and forskolin was determined as previously described $(22,24)$. The "standard" reaction mixture designed to detect hormone stimulation $(22,24)$ included $0.1 \mathrm{mM} \mathrm{MgATP}$ with $0.5 \mathrm{mM} \mathrm{MgCl}_{2}$ in excess, $10^{-5} \mathrm{M} \mathrm{GTP}, 10$ $\mathrm{mM}$ phosphocreatine, and $1 \mathrm{mM}$ cAMP to inhibit endogenous phosphodiesterases activity. A second assay condition, termed the "GppNHp (guanylyl imidodiphosphate) condition," consisted of the above mixture minus GTP, plus $10^{-6} \mathrm{M}(-)$ propranolol. A third assay condition was used to assess $\mathrm{Mn}^{2+}$ stimulation (" $\mathrm{Mn}^{2+}$ condition") and consisted of the $\mathrm{Gpp}(\mathrm{NH}) \mathrm{p}$ condition minus $\mathrm{MgCl}_{2}$. Recovery was determined by trace labeling with $\left.{ }^{3} \mathrm{H}\right] \mathrm{cAMP}$, and the reaction was started by trace labeling with $\left[\alpha-{ }^{32} \mathrm{P}\right] \mathrm{ATP}$. Newly formed $\left[{ }^{32} \mathrm{P}\right] \mathrm{cAMP}$ was recovered by the technique of Salomon et al. (27). Recovery was consistently $70-95 \%$ of added $\left[{ }^{3} \mathrm{H}\right]$ cAMP.

\section{Tissue catecholamine and NPY measurements}

Tissue norepinephrine, dopamine, and epinephrine levels were measured radioenzymatically in $\mathrm{HCl}$-extracted supernatants by using the Cat-a-Kit (Amersham Corp., Arlington Heights, IL). Results were expressed as nanograms of catecholamine per grams of original tissue wet (blotted) weight. Plasma norepinephrine was also measured by Cat-a$\mathrm{Kit}$ and was expressed as picograms per milliliter plasma.

NPY levels were measured by radioimmunoassay (RIA). One-half of the homogenized aliquot was used for protein measurements, and the other half was used for RIA. The latter was centrifuged for $30 \mathrm{~min}$ at $3,500 \mathrm{~g}$ and the supernatant was removed, frozen, and lyophilized. The lyophilized tissue samples were reconstituted in $250 \mu \mathrm{l}$ of PBS plus Triton buffer and centrifuged for $30 \mathrm{~min}$ at $3,500 \mathrm{~g}$ at $4^{\circ} \mathrm{C}$. The supernatant $(200 \mu \mathrm{l})$ was separated into plastic tubes to which specific antisera (100 $\mu \mathrm{l}$ at $1: 160,000$ dilution) was added. The assay tubes together with a series of standard NPY dilutions (5-500 pg per tube, four tubes per dilution) were then incubated for $96 \mathrm{~h}$ at $4^{\circ} \mathrm{C}$. [ $\left.{ }^{125} \mathrm{I}\right] \mathrm{NPY}$ (New England Nuclear, Boston, MA) $5,000-6,000 \mathrm{cpm} / \mathrm{min}$ per $100 \mu \mathrm{l}$, was added to each tube which was then incubated for an additional $48 \mathrm{~h}$ at $4^{\circ} \mathrm{C}$. After incubation, dextran-coated charcoal was added to each tube and the resultant mixture was centrifuged for $30 \mathrm{~min}$ at $4^{\circ} \mathrm{C}$. The amount of NPY in each tube, expressed as picograms per tube, was calculated from the bound to reference ratio. The antibody for the assay was derived from NPY-immunized rabbit antisera which exhibited $<1 \%$ cross-reactivity with all peptides currently recognized to have significant homology to the NPY amino acid sequence. Sensitivity for this assay is $5 \mathrm{pg} / \mathrm{ml}$. Protein concentrations of tissue samples were determined by the Peterson modification of the Lowry method (28), and NPY results were expressed as picograms per milligram of homogenate protein.

\section{Creatine kinase measurements}

Soluble creatine kinase activity was measured in the supernatants of the 1,085- $g$ centrifugation used to process a particulate fraction of adenylate cyclase assays, using a previously described spectrophotometric technique (22).

\section{Mechanical responses of isolated right ventricular trabeculae}

Mechanical responses of isolated right ventricular trabeculae harvested from freshly explanted organ donors or transplant recipients was measured as previously described $(11,22)$. Briefly, trabeculae of uniform size (1-2 $\times 6-8 \mathrm{~mm})$ were mounted in an eight-chamber muscle bath containing Tyrode's solution bubbled with $95 \%$ oxygen and $5 \% \mathrm{CO}_{2}$ to give a final $\mathrm{pH}$ of 7.45 . Trabeculae were field stimulated at $10 \%$ above threshold, and resting tension was set at the length that produced the maximum degree of systolic contraction, usually $\sim 1 \mathrm{~g}$. After a 2-h equilibration period, full-dose response curves to isoproterenol were performed using $0.5 \mathrm{log}$ unit dose increments between $10^{-9}$ and $10^{-5}$ M. After completion of the isoproterenol dose-response curve and washout of isoproterenol, the maximal response to calcium was measured by administering calcium chloride at a final concentrations of $2.5,5$, and then $10 \mathrm{mM}$. Tension was recorded as the stimulated tension minus baseline tension, and the maximum response was taken as the greatest amount of net tension produced at any point in the dose-response curve.

\section{Statistical analysis}

Differences in the left or right ventricles among the three groups of hearts ("intergroup" comparison) were assessed by using ANOVA and the Scheffe multiple comparison test. Differences between measurements in left vs. right ventricles were compared by using a paired $t$ test, with a $P<0.05$ in a two-tailed distribution considered to be statistically significant. Data are presented as the group mean plus standard error of the mean.

\section{Chemicals and drugs}

All drugs and chemicals were obtained from commercially available sources using biochemical or molecular biology grade material.

\section{Results}

\section{Clinical summary}

Table I gives the average age and sex of the three groups. There were no significant differences in age among the three groups, but the IDC group (group B) had relatively fewer females compared to the other two groups.

Catheterization data for groups $\mathrm{B}$ and $\mathrm{C}$ are also given in Table I. Biventricular failure is evident in group B (IDC) by elevated right atrial mean and pulmonary wedge mean pressures and reduced cardiac index. The mean left ventricular ejection fraction in group B was $0.15 \pm 0.01$ (SEM). In group C, $\mathrm{PPH}$ subjects isolated right ventricular failure is documented by an elevated right atrial mean pressure and a reduced cardiac index in the presence of a normal mean pulmonary artery wedge pressure. In the PPH group severe pressure overload of the right ventricle is documented by a markedly elevated pulmonary artery mean pressure that is nearly twice as high as in the IDC group. Echocardiographic evaluation revealed normal left ventricular function in all subjects in group $C$. In seven PPH subjects, central venous plasma norepinephrine was measured and averaged $513 \pm 131 \mathrm{pg} / \mathrm{ml}$ (range 229-1198).

\section{$\beta$-Adrenergic receptor measurements}

Fig. 1 gives ICYP-CGP 20712A competition curve data in nonfailing left and failing right ventricle from a PPH patient. The left and right ventricular $\beta$ receptor density in the heart shown in Fig. 1 was, respectively, 91.5 and $45.2 \mathrm{fmol} / \mathrm{mg}$. It can be seen from Fig. 1 that two classes of binding sites are present, with CGP 20712A displacing [ ${ }^{125}$ I]ICYP from a high-affinity class in the nanomolar range, and a low-affinity class in the micromolar range.

Intergroup comparison. In Table II are given mean values for $\beta$-adrenergic receptor density as determined by maximum ICYP binding, ICYP dissociation constant $\left(K_{\mathrm{D}}\right)$, the percentage of $\beta_{1}$ - and $\beta_{2}$-adrenergic receptors as determined by resolution of ICYP-selective ligand competition curves, and $\beta_{1}$ and $\beta_{2}$ 


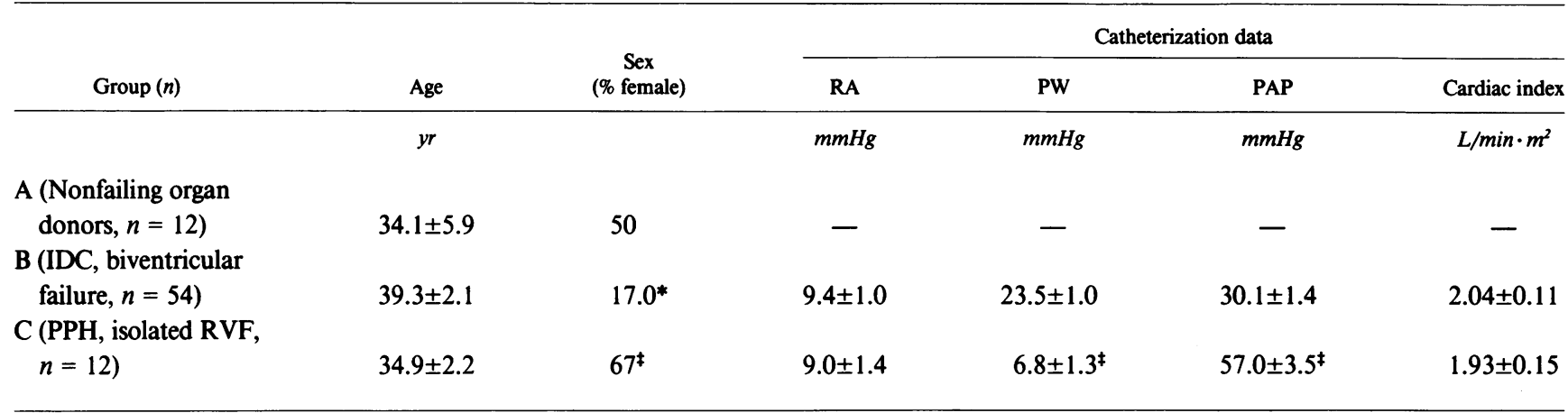

Values are given \pm SEM. Abbreviations: RA, right atrial mean pressure; PW, pulmonary wedge mean pressure; PAP, pulmonary artery mean pressure. ${ }^{*} P<0.05$ vs. A. ${ }^{\ddagger} P<0.05$ vs. B.

receptor densities. As shown in Table II, there is a marked reduction in $\beta$ receptor density in both the left and right ventricles of group B when compared with nonfailing organ donor controls (group A). On the other hand, in the PPH group (group $\mathrm{C}$ ) the failing right ventricle has a markedly reduced $\beta$
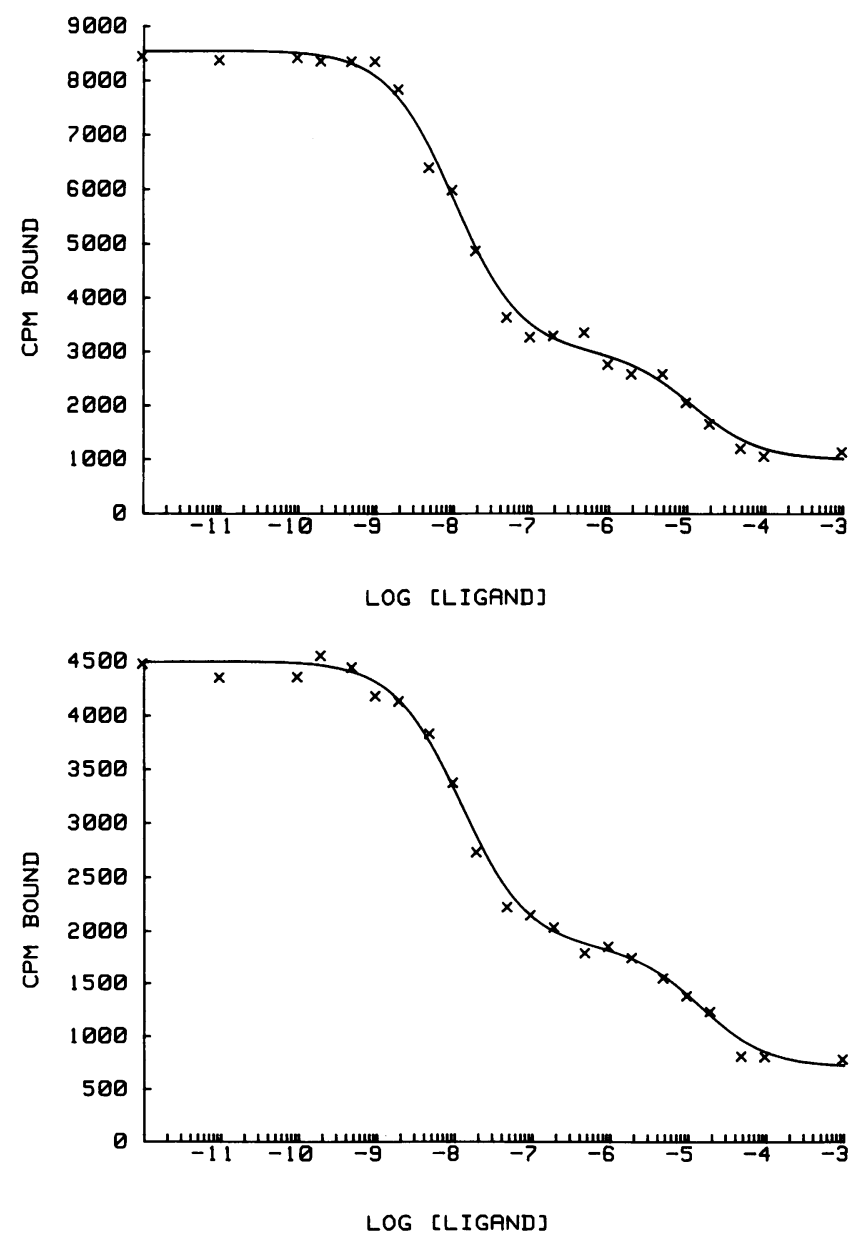

Figure 1. [ ${ }^{125}$ I]ICYP-CGP 20712A competition curves in a group C, PPH subject. Top panel: left ventricle $\left(\beta_{1}=74.8 \%, \beta_{2}=25.2 \%, K_{\mathrm{H}}\right.$ $\left(\beta_{1}\right)=0.93 \mathrm{nM}, K_{\mathrm{L}}\left(\beta_{2}\right)=1.0 \mu \mathrm{M}$. Bottom panel: right ventricle $\left(\beta_{1}\right.$ $=72.4 \%, \beta_{2}=27.6 \%, K_{\mathrm{H}}\left(\beta_{1}\right)=0.93 \mathrm{nM}, K_{\mathrm{L}}\left(\beta_{2}\right)=1.10 \mu \mathrm{M}$. receptor density while the nonfailing left ventricle has a total $\beta$ receptor density that is not significantly different from group $\mathrm{A}$ left ventricles.

Similarly, $\beta_{1}$ receptor density is also decreased in failing left and right ventricles from group $B$ and right ventricles from group $\mathrm{C}$, compared with nonfailing left and right ventricles from group $A$ and nonfailing left ventricle from group $C$. In contrast, $\beta_{2}$ receptor density did not differ among the left or right ventricles in groups $A$ and $B$ or in the right ventricles of group $C$. However, $\beta_{2}$ receptor density in group $C$ left ventricles tended to be increased compared to all groups, and compared to the left ventricles of group B the increase achieved statistical significance.

As can be seen in Table II, the selective loss of $\beta_{1}$-adrenergic receptors in all failing ventricles resulted in a decrease in the percent of $\beta_{1}$ and an increase in the percentage of $\beta_{2}$ receptors in the left and right ventricles of group $B$ and the right ventricles of group $\mathrm{C}$.

In a subgroup of five group $C$ subjects with decreased right ventricular $\beta$ and $\beta_{1}$ receptor densities (respectively $40.5 \pm 6.2$ and $26.6 \pm 4.1$ vs. $75.1 \pm 4.4$ and $55.7 \pm 4.0 \mathrm{fmol} / \mathrm{mg}$ in left ventricle, both paired $t$ value for LV vs. RV $<0.01$ ), membrane yield was assessed by measuring $10 \mathrm{mM} \mathrm{NaF}$-stimulated adenylate cyclase activity in crude membrane preparations used for radioligand binding. There was no significant difference in activation of adenylate cyclase in left $(60.1 \pm 12.5 \mathrm{pmol}$ cAMP/ $\mathrm{min} \cdot \mathrm{mg}$ protein) vs. right $(61.3 \pm 7.9)$ ventricles.

Because of the sex differences noted in Table I we analyzed $\beta$-adrenergic receptor and neurotransmitter data with respect to male vs. female values. There were no sex-related differences $(P>0.05)$ in any group or chamber for any parameter examined, including total $\beta$ receptor density, $\beta_{1}$ receptor density, $\beta_{2}$ receptor density, or tissue norepinephrine, dopamine, epinephrine, and NPY levels.

Left vs. right ventricles. Paired $t$ analysis of $\beta$-adrenergic receptor data in left vs. right ventricular preparations of all three groups is given in Table II; selected data for group C are shown in Fig. 2. Relative to nonfailing left ventricles group $\mathrm{C}$ failing right ventricles demonstrated significant reductions in total $\beta$ and $\beta_{1}$ receptor densities, whereas $\beta_{2}$ receptor density was unchanged. In group $C$ failing right ventricles the percent $\beta_{1}$ was lower and the percent $\beta_{2}$ was higher than in nonfailing left ventricles, whereas ICYP $K_{\mathrm{D}}$ was not different. 
Table II. Adrenergic Receptor Data

\begin{tabular}{|c|c|c|c|c|c|c|c|c|c|}
\hline \multirow{2}{*}{ Group } & & \multicolumn{3}{|c|}{$\beta$ receptor density } & \multirow{2}{*}{$\begin{array}{l}\text { ICYP } \\
K_{\mathrm{D}}\end{array}$} & \multirow[b]{2}{*}{$\% \beta_{1}$} & \multirow[b]{2}{*}{$\% \beta_{2}$} & \multirow{2}{*}{$\begin{array}{c}\alpha_{1} \text { receptor } \\
\text { density }\end{array}$} & \multirow{2}{*}{$\begin{array}{c}\text { IBE-2254 } \\
K_{\mathrm{D}} \\
\end{array}$} \\
\hline & & Total $\beta$ & $\beta_{1}$ & $\beta_{2}$ & & & & & \\
\hline & & & $\mathrm{fmol} / \mathrm{mg}$ & & $p M$ & & & $\mathrm{fmol} / \mathrm{mg}$ & $p M$ \\
\hline \multicolumn{10}{|l|}{ A (Nonfailing } \\
\hline$n=12)$ & LV & $87.7 \pm 7.4$ & $68.0 \pm 6.4$ & $19.6 \pm 2.3$ & $11.9 \pm 2.7$ & $77.0 \pm 2.3$ & $22.9 \pm 2.2$ & $8.8 \pm 1.2$ & $39.5 \pm 12.1$ \\
\hline & $\mathbf{R V}$ & $102.1 \pm 9.2^{\S}$ & $81.2 \pm 10.0^{\S}$ & $18.0 \pm 2.7$ & $12.3 \pm 3.0$ & $80.0 \pm 3.0$ & $19.9 \pm 2.9$ & $6.8 \pm 4.0$ & $27.4 \pm 20.0$ \\
\hline \multicolumn{10}{|l|}{ B (Biventricular } \\
\hline failure, $n=54$ ) & $\begin{array}{l}\text { LV } \\
\text { RV }\end{array}$ & $\begin{array}{l}51.1 \pm 1.9^{*} \\
47.8 \pm 2.6^{*}\end{array}$ & $\begin{array}{l}32.8 \pm 1.6^{*} \\
33.9 \pm 2.5^{*}\end{array}$ & $\begin{array}{l}18.2 \pm 0.9 \\
17.1 \pm 1.1\end{array}$ & $\begin{array}{l}15.3 \pm 1.8 \\
15.2 \pm 2.2\end{array}$ & $\begin{array}{l}63.4 \pm 1.5^{*} \\
65.6 \pm 2.2^{*}\end{array}$ & $\begin{array}{l}36.1 \pm 1.4^{*} \\
34.4 \pm 2.0^{*}\end{array}$ & $\begin{array}{l}17.6 \pm 3.3 \\
15.9 \pm 3.2\end{array}$ & $\begin{array}{l}41.9 \pm 5.3 \\
38.9 \pm 7.3\end{array}$ \\
\hline \multicolumn{10}{|l|}{$\mathrm{C}(\mathrm{PPH}$, isolated } \\
\hline $\mathrm{RVF}, n=12)$ & LV & $85.4 \pm 6.1^{\ddagger}$ & $62.1 \pm 4.2^{\ddagger}$ & $24.9 \pm 3.4^{\ddagger}$ & $9.4 \pm 1.6$ & $72.0 \pm 2.5^{\ddagger}$ & $28.2 \pm 2.2^{\ddagger}$ & $16.4 \pm 2.7$ & $39.3 \pm 11.7$ \\
\hline & RV & $41.9 \pm 4.0^{* \S}$ & $23.2 \pm 2.6^{* \S}$ & $19.6 \pm 3.7$ & $10.2 \pm 2.5$ & $56.0 \pm 5.6^{* \S}$ & $41.5 \pm 4.6^{* \S}$ & $14.6 \pm 2.8$ & $34.0 \pm 10.7$ \\
\hline
\end{tabular}

Values are given as mean \pm SEM. Abbreviations: $\mathrm{LV}$, left ventricle; $\mathrm{RV}$, right ventricle. ${ }^{*} P<0.05$ vs. respective chamber in $\mathrm{A} .{ }^{\ddagger} P<0.05$ vs. respective chamber in B. ${ }^{\S} P<0.05$ vs. LV.

The only differences between left and right ventricles in groups $\mathrm{A}$ and $\mathrm{B}$ were higher total $\beta$ and $\beta_{1}$ receptor densities in group A right ventricles vs. paired left ventricles. In contrast, $\beta_{2}$ receptor density was not different in the right vs. left ventricles of nonfailing hearts.

\section{$\beta$-Agonist binding characteristics}

Intergroup comparison. In Table III are given $\beta$-agonist binding data derived from ICYP-isoproterenol competition curves. The curve slope (Hill coefficient) was significantly $(P<0.05)$ less than unity in all groups, indicating complex binding. The overall position of the ICYP-isoproterenol competition curves did not vary among the various groups $\left(K_{\mathrm{i}} 37-74 \mathrm{nM}\right)$. By computer modeling the best fit in most cases was for two sites in all groups (left ventricle-6 of 9 in group A, 20 of 23 in group $B$, and 9 of 11 in group C; right ventricle -8 of 8 in group A, 9 of 11 in group $B$, and 10 of 11 in group $C$ ).

If a high-affinity isoproterenol binding site is defined as a $K_{\mathrm{H}}$ of $<30 \mathrm{nM}$, all groups with the exception of group C left ventricles exhibited a minority $(\sim 30 \%)$ of binding sites in a high-affinity state. The $K_{\mathrm{H}}$ for group C left ventricles was significantly higher than for group A or B left ventricles, but was not significantly different from the value in group $C$ right ventricles. The $K_{\mathrm{L}}$ did not vary among the various groups. The density of the high-affinity $\left(K_{H}\right)$ isoproterenol binding sites was or tended to be decreased in group B left and right ventricles and in group $C$ right ventricles, whereas group $C$ left ventricles had a value similar to group A left ventricles.

Left vs. right ventricles. As shown in Table III and Fig. 2, the only significant difference between left and right ventricular agonist binding data was for the density of high affinity sites in group $\mathrm{C}$, which was lower in right vs. left ventricles.

\section{$\alpha_{1}$-Adrenergic receptor density}

Intergroup comparison. The $\alpha_{1}$ receptor density is given in Table II. There were no differences in $\alpha_{1}$ receptor density or IBE2254 affinity in any of the groups, for either right or left ventricles.

Left vs. right ventricles. The $\alpha_{1}$ receptor density and IBE$2254 K_{\mathrm{D}}$ did not differ in left vs. right ventricle for any group (Table II).

\section{$\beta$ receptor measurements in light and heavy density membrane fractions}

In Table IV are given $\beta$ receptor density and ICYP $K_{\mathrm{D}}$ measurements in light and heavy membrane fractions. As can be seen, right ventricular $B_{\max }$ is significantly decreased in both fractions, whereas $K_{\mathrm{D}}$ is unchanged in failing right vs. nonfailing left ventricles.

\section{Tissue catecholamine and NPY levels}

Intergroup comparison. Table $\mathrm{V}$ gives mean values for tissue catecholamine and NPY levels. For norepinephrine, the group B left ventricular value was $43 \%$ lower than the value in group A nonfailing left ventricles $(P<0.05)$, and $63 \%$ lower than the value in group $C$ nonfailing left ventricles $(P<0.05)$. In right ventricles norepinephrine was similarly reduced in group B (by $42 \%$ relative to group A right ventricles, $P<0.05$ ), and more severely reduced in group C (by $82 \%$ compared with group A, $P$ $<0.05$ vs. group A or B). NPY exhibited a pattern similar to norepinephrine, with failing chambers having lower values than respective nonfailing chambers.

Tissue dopamine exhibited a different pattern, being or tending to be higher in the left and right ventricles of group A relative to either group B or C; values in group B left and right ventricles and group $C$ right ventricles reached statistical significance relative to the respective chambers in group A. Tissue epinephrine exhibited a pattern similar to dopamine, except that statistical significance relative to group A left or right ventricles was achieved in group B left ventricles and both ventricles of group $\mathrm{C}$.

Six of the nine group A ventricles in whom catecholamines were measured were not exposed to any dopamine within $48 \mathrm{~h}$ of organ harvest. Tissue catecholamines (in $\mathrm{pg} / \mathrm{ml}$ ) in these six did not differ significantly from the group as a whole: $\mathrm{LV}$, norepinephrine $1,006 \pm 196$, dopamine $266 \pm 131$, epinephrine $188 \pm 69$; RV, norepinephrine $1,050 \pm 206$, dopamine $226 \pm 77$, epinephrine $124 \pm 31$.

Left vs. right ventricles. Relative to paired nonfailing left ventricles group $\mathrm{C}$ failing right ventricle exhibited a significant reduction in norepinephrine, epinephrine, and NPY levels, with the degree of reduction most pronounced for norepinephrine (reduced by $84 \%$ ). In contrast, group B failing right ventri- 

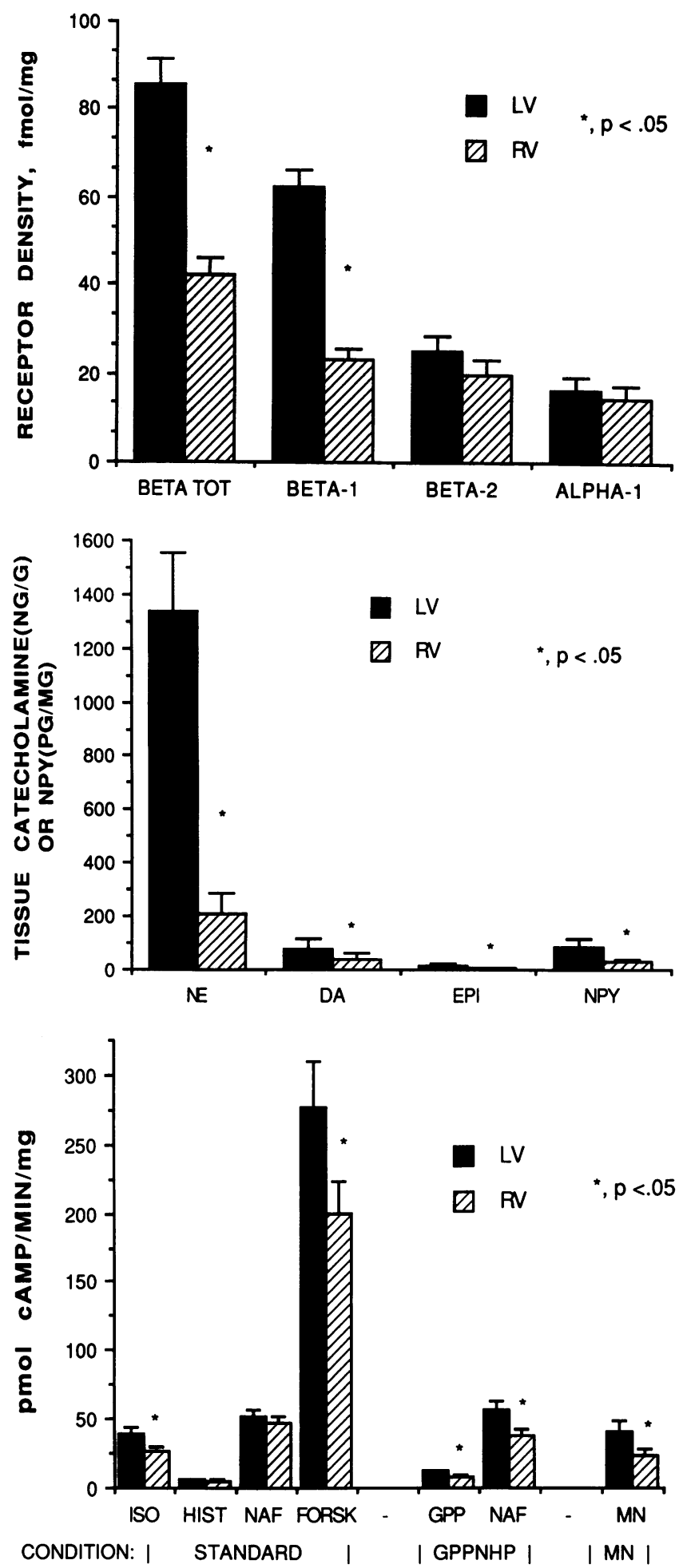

Figure 2. Top panel: adrenergic receptor data in group C ( $n=12 \mathrm{PPH}$ hearts). Middle panel: tissue catecholamine and NPY levels in group $\mathrm{C}(n=5 \mathrm{PPH}$ hearts). Bottom panel: selected adenylate cyclase activities in group $\mathrm{C}(n=12 \mathrm{PPH}$ hearts).

cles had significantly higher norepinephrine levels than the corresponding left ventricles, and values in group A right ventricles also tended to be higher than in the corresponding left ventricles.

\section{Adenylate cyclase data}

Intergroup comparison. Adenylate cyclase measurements were made in a carefully handled particulate fraction of left and right ventricular myocardium. Activity was measured under conditions designed to detect ( $a$ ) maximum $\beta$-agonist activity (standard condition), (b) stimulation by guanine nucleotides ( $\mathrm{Gpp}(\mathrm{NH}) \mathrm{p}$ condition), and (c) stimulation of the catalytic unit by $\mathrm{MnCl}_{2}\left(\mathrm{Mn}^{2+}\right.$ condition). The results are given in Tables VI and VII.

As shown in Table VI, under standard conditions net (maximum minus basal activities) stimulation by the $\beta$ agonists isoproterenol or zinterol was or tended to be decreased in failing chambers. The isoproterenol difference between groups $B$ and $\mathrm{C}$ left ventricles and groups $\mathrm{B}$ and $\mathrm{A}$ right ventricles achieved statistical significance, whereas zinterol stimulation was reduced in both left and right ventricles of group B relative to the respective chambers in group A. Basal activity was significantly reduced only in group B right ventricles, compared to group A nonfailing controls. Hormone stimulation by vasoactive intestinal peptide (VIP) or histamine and fluoride stimulation were not different among the various groups. Forskolin stimulation tended to be decreased in all failing chambers, but none of the values were significantly different from nonfailing group A controls.

Table VII gives adenylate cyclase stimulation data under $\mathrm{Gpp}(\mathrm{NH}) \mathrm{p}$ and $\mathrm{Mn}^{2+}$ conditions. Relative to group A left or right ventricles, both ventricles in group $B$ and group $C$ right ventricles had or tended to have reduced $\mathrm{Gpp}(\mathrm{NH}) \mathrm{p}$ stimulation, with group B left ventricles achieving statistical significance relative to group A left ventricles.

With the $\mathrm{Mn}^{2+}$ condition, $\mathrm{Mn}^{2+}$ stimulation was markedly decreased in failing group $\mathrm{C}$ right ventricles relative to group $\mathrm{A}$ nonfailing right ventricular controls. $\mathrm{Mn}^{2+}$ stimulation was also decreased in group $\mathrm{B}$ right ventricles relative to group A nonfailing controls, but the decrease in group $\mathrm{B}$ was less than in group C (respectively by $42 \%$ vs. $64 \%$ ).

Left vs. right ventricle. Relative to paired nonfailing left ventricles, under standard assay conditions no differences in adenylate cyclase stimulation were apparent in nonfailing left vs. right ventricles of group A (Table VI). In contrast, relative to nonfailing left ventricles failing right ventricles in group $\mathrm{C}$ exhibited significant reductions in adenylate cyclase basal activity and stimulation of adenylate cyclase by isoproterenol, zinterol, and forskolin (Table VI and Fig. 2). VIP, histamine, and $\mathrm{NaF}$-stimulated adenylate cyclase activity did not differ in right vs. left ventricles in group C. Group B right vs. left ventricles also yielded significant $(P<0.05)$ reductions in basal activity, isoproterenol stimulation, and fluoride stimulation, while forskolin stimulation nearly reached statistical significance $(P$ $=0.052$ ).

With the $\mathrm{Gpp}(\mathrm{NH}) \mathrm{p}$ assay condition, $\mathrm{Gpp}(\mathrm{NH}) \mathrm{p}$ stimulation differed in the right vs. left ventricles of group A, with the right ventricle being 20\% lower (Table VII). For group C (Table VII and Fig. 2) failing right vs. nonfailing left ventricles demonstrated a decrease in adenylate cyclase basal activity (by $41 \%$ ), as well as a reduced stimulation of adenylate cyclase by Gpp(NH)p (by 29\%) and NaF (by $31 \%$ ). In these same seven preparations from PPH subjects, NaF stimulation was not decreased under standard assay conditions (in left ventricle $49.7 \pm 9.1$ vs. $45.3 \pm 8.6 \mathrm{pmol} \mathrm{cAMP} / \mathrm{min} \cdot \mathrm{mg}$ in right ventricle, 


\begin{tabular}{|c|c|c|c|c|c|c|c|c|c|}
\hline \multirow[b]{2}{*}{ Group } & & \multicolumn{2}{|c|}{ Curve characteristics } & \multicolumn{2}{|c|}{$\begin{array}{l}\text { High, low affinity dissociation } \\
\text { constants }\end{array}$} & \multicolumn{2}{|c|}{$\%$ high and low affinity sites } & \multicolumn{2}{|c|}{$\begin{array}{l}\text { Density high and low group } \\
\text { affinity sites }\end{array}$} \\
\hline & & $K_{1}$ & Slope & $K_{\mathrm{H}}$ & $K_{\mathrm{L}}$ & $K_{\mathrm{H}}$ & $K_{\mathrm{L}}$ & $K_{\mathrm{H}}$ & $K_{\mathrm{L}}$ \\
\hline & & \multicolumn{2}{|c|}{$n M$} & \multicolumn{2}{|c|}{$n M$} & \multicolumn{2}{|c|}{$\%$} & \multicolumn{2}{|c|}{$\mathrm{fmol} / \mathrm{mg}$} \\
\hline \multicolumn{10}{|l|}{ A (Nonfailing, } \\
\hline$n=9)$ & LV & $74 \pm 42$ & $0.66 \pm 0.05$ & $4.2 \pm 1.1$ & $421 \pm 231$ & $31.0 \pm 4.6$ & $67.2 \pm 4.5$ & $29.8 \pm 6.6$ & $62.3 \pm 5.9$ \\
\hline & RV & $37 \pm 13$ & $0.74 \pm 0.06$ & $4.3 \pm 3.7$ & $87 \pm 32$ & $26.5 \pm 8.0$ & $72.0 \pm 8.0$ & $25.4 \pm 7.6$ & $79.9 \pm 8.4$ \\
\hline \multicolumn{10}{|l|}{ B (Biventricular } \\
\hline \multirow[t]{2}{*}{ failure, $n=23$ ) } & LV & $44 \pm 9$ & $0.73 \pm 0.03$ & $5.4 \pm 1.7$ & $112 \pm 20$ & $31.5 \pm 25.1$ & $66.3 \pm 5.0$ & $15.1 \pm 2.3$ & $34.1 \pm 3.6^{*}$ \\
\hline & $\mathbf{R V}$ & $42 \pm 17$ & $0.81 \pm 0.10$ & $3.9 \pm 1.9$ & $147 \pm 64$ & $30.0 \pm 8.5$ & $68.2 \pm 8.4$ & $15.0 \pm 3.8$ & $28.9 \pm 5.8^{*}$ \\
\hline \multicolumn{10}{|l|}{$\mathrm{C}$ (PPH, isolated } \\
\hline RV failure, & LV & $51 \pm 7$ & $0.77 \pm 0.02$ & $14.8 \pm 3.5^{* \neq}$ & $180 \pm 27$ & $51.1 \pm 9.8$ & $44.6 \pm 9.8$ & $43.7 \pm 9.2^{\ddagger}$ & $39.5 \pm 10.4$ \\
\hline$n=10)$ & RV & $60 \pm 9$ & $0.77 \pm 0.02$ & $9.2 \pm 2.6$ & $145 \pm 19$ & $33.8 \pm 8.8$ & $62.0 \pm 8.4$ & $15.0 \pm 3.8^{\S}$ & $27.2 \pm 5.0^{*}$ \\
\hline
\end{tabular}

Values are given \pm SEM. Abbreviations are as in Table II. ${ }^{*} P<0.05$ vs. A. ${ }^{\ddagger} P<0.05$ vs. B. ${ }^{\S} P<0.05$ vs. LV.

$P=$ NS). Right vs. left ventricular values for Gpp(NH)p stimulation were lower in group $\mathrm{A}$ but not in group $\mathrm{B}$, where $\mathrm{NaF}$ stimulation was not significantly different in group A or B.

Using the $\mathrm{Mn}^{2+}$ condition, $\mathrm{PPH}$ right ventricles exhibited a marked reduction in basal activity and $\mathrm{Mn}^{2+}$ stimulation of adenylate cyclase, by respective amounts of $48 \%$ and $43 \%$ when compared to $\mathrm{PPH}$ left ventricles. In contrast, $\mathrm{Mn}^{2+}$ stimulation in left vs. right ventricles was not significantly different in groups A and B, and in fact tended to be higher in group A right compared to left ventricles.

\section{Muscle contraction data}

As can be seen in Table VIII, trabeculae removed from severely failing PPH right ventricles exhibited a marked reduction in isoproterenol mediated tension responses, whereas calcium-induced contractile responses were not significantly different from nonfailing controls. The percent decrease in isoproterenol responsiveness was by $58 \%$, whereas the IDC subjects in group B exhibited a decrease in isoproterenol response by $33 \%$.

\section{Discussion}

The development of isolated right ventricular failure in subjects with PPH allowed us to examine which of the previously described abnormalities of the myocardial adrenergic neuroeffector mechanism are related to local (occurring only in failing right ventricles) vs. systemic (occurring in both ventricles)

Table IV. $\beta$-Receptor Density $\left(B_{\max }\right)$ and ICYP $K_{D}$ in Light and Heavy Membrane Fractions $(n=5)$

\begin{tabular}{cccccc}
\hline & \multicolumn{3}{c}{ Heavy } & & \multicolumn{2}{c}{ Light } \\
\cline { 2 - 3 } \cline { 5 - 6 } Chamber & $B_{\max }$ & $K_{\mathrm{D}}$ & & $B_{\max }$ & $K_{\mathrm{D}}$ \\
\hline & $f m o l / m g$ & $p M$ & & $f m o l / m g$ & $p M$ \\
LV & $39.9 \pm 9.4$ & $16.5 \pm 2.5$ & & $106.1 \pm 19.9$ & $19.1 \pm 4.1$ \\
RV & $17.0 \pm 2.9^{*}$ & $16.9 \pm 3.2$ & & $40.4 \pm 5.8^{*}$ & $18.4 \pm 3.2$
\end{tabular}

Values are given \pm SEM. Abbreviations are as in Table II. ${ }^{*} P<$ $0.05 \mathrm{LV}$. causes. The degree of right ventricular failure as judged by cardiac index and right atrial mean pressure was comparable in PPH subjects and control subjects exhibiting biventricular failure from IDC, and values from PPH and IDC ventricles were compared to nonfailing control left and right ventricles removed from organ donors.

Failing right ventricles removed from subjects with $\mathrm{PPH}$ exhibited selective (compared to PPH left ventricle) $\beta_{1}$-receptor down-regulation, depletion of tissue norepinephrine and NPY, decreased adenylate cyclase basal activity, and decreases in isoproterenol, zinterol, Gpp(NH)p, forskolin, and $\mathrm{Mn}^{2+}$ stimulation of adenylate cyclase. These abnormalities in PPH failing right ventricles were directionally similar to, but tended to be more pronounced than, corresponding findings in failing right ventricles removed from subjects with IDC. In contrast, nonfailing left ventricular tissue removed from PPH subjects contained levels of $\beta$-adrenergic receptors, norepinephrine and NPY, and adenylate cyclase activities that were not significantly different from nonfailing left ventricles removed from organ donors. These data indicate that in the failing human heart the previously described adrenergic neuroeffector abnormalities (11-16, 22-24, 26) are "chamber specific" (29) in their distribution, and are confined only to chambers that are failing when the clinical syndrome of heart failure is present. This in turn implies that factors producing these adrenergic abnormalities are under local, rather than systemic control.

For adrenergic receptor abnormalities, the $\beta_{1}$ subtype was the only receptor reduced in PPH right ventricles. The $\beta_{2}$ and $\alpha_{1}$ receptor subtypes were not reduced in PPH right ventricles compared to nonfailing donor left or right ventricles or compared to PPH left ventricles, which is similar to previous reports $(11,12,26)$ of the behavior of these receptors in failing ventricular myocardium. In PPH left ventricles $\beta_{2}$ receptor density tended to be higher than in the other groups, and the difference (by $31 \%$ ) reached statistical significance when compared to IDC left ventricles. The only other reported situation in which human ventricular myocardial $\beta_{2}$ receptor density is increased is in the transplanted human heart (30). The reason why these two situations exhibit increased myocardial $\beta_{2}$ adrenergic receptor density is unclear.

The $\beta_{1}$-adrenergic receptor and adrenergic neurotransmit- 
Table V. Tissue Catecholamines, NPY, and Soluble Creatine Kinase Activity

\begin{tabular}{|c|c|c|c|c|c|c|}
\hline \multirow[b]{2}{*}{ Group } & & \multicolumn{3}{|c|}{ Tissue catecholamines } & \multirow{2}{*}{$\begin{array}{l}\text { Tissue } \\
\text { NPY }\end{array}$} & \multirow{2}{*}{$\begin{array}{l}\text { Soluble creatine } \\
\text { kinase activity }\end{array}$} \\
\hline & & $\mathrm{NE}$ & DA & EPI & & \\
\hline & & \multicolumn{3}{|c|}{$n g / g$ wet weight } & pg/mg protein & $I U / g$ wet weight \\
\hline \multicolumn{7}{|l|}{ A (Nonfailing, } \\
\hline \multirow[t]{2}{*}{$n=9)$} & LV & $865 \pm 147$ & $245 \pm 86$ & $135 \pm 52$ & $92.8 \pm 8.2$ & $1,078 \pm 73$ \\
\hline & RV & $1,183 \pm 180$ & $275 \pm 67$ & $94 \pm 25$ & $108 \pm 18.3$ & $1,110 \pm 102$ \\
\hline \multicolumn{7}{|l|}{ B (Biventricular } \\
\hline failure, & LV & $497 \pm 43^{*}$ & $59 \pm 15^{*}$ & $43 \pm 10^{*}$ & $45.1 \pm 5.1^{*}$ & $899 \pm 40$ \\
\hline$n=39)$ & RV & $688 \pm 93^{* \delta}$ & $44 \pm 9^{*}$ & $54 \pm 14$ & $55.1 \pm 6.3^{*}$ & $779 \pm 32^{* 1}$ \\
\hline \multicolumn{7}{|l|}{$\mathrm{C}$ (PPH isolated } \\
\hline RV failure, & LV & $1,337 \pm 216^{\ddagger}$ & $79 \pm 39$ & $18 \pm 5^{*}$ & $96.1 \pm 42.1^{\ddagger}$ & $955 \pm 112$ \\
\hline$n=5)$ & $\mathbf{R V}$ & $209 \pm 75^{* \neq 8}$ & $41 \pm 18^{*}$ & $7 \pm 2^{* \neq 5}$ & $34.3 \pm 13.4^{* 5}$ & $721 \pm 56^{*}$ \\
\hline
\end{tabular}

Values are given \pm SEM. Abbreviations: NE, norepinephrine; DA, dopamine; EPI, epinephrine; and as given in Table II. ${ }^{*} P<0.05$ vs. respective chamber in $\mathrm{A}$. ${ }^{\ddagger} P<0.05$ vs. respective chamber in $\mathrm{B}$. $P<0.05$ vs. $\mathrm{LV}$.

ter differences in PPH right vs. left ventricles appeared to be related to the presence of failing heart muscle, as the age of group C individuals was not different from groups A and B, and gender, which was distributed differently among the three groups, had no effect on any measured parameter. The downregulation of $\beta_{1}$-adrenergic receptors noted in group $C$ right ventricles appeared to be due to loss of receptors from all cellular pools, as $\beta$-receptor down-regulation occurred equally in light- and heavy-density membrane compartments; this argues against "internalization" into a microvesicular fraction as the explanation for loss of $\beta_{1}$ receptors from crude membrane fractions. However, sequestered receptors (31) might not have been detected by the methods used in this investigation, and undetected receptor sequestration could have accounted for the "uncoupling" of $\beta_{2}$ receptors observed in all failing ventricles.

Tissue norepinephrine levels were reduced by over $80 \%$ in PPH right compared to $P P H$ left ventricles, and values in $P P H$ right ventricles were also lower than in IDC right ventricles. In contrast, tissue norepinephrine levels in PPH left ventricles were significantly higher than values in IDC left ventricles but not statistically significant from values in nonfailing donor left ventricles. Tissue NPY levels exhibited a similar pattern. These data indicate that the previously described depletion of the adrenergic neurotransmitter norepinephrine (14-16) and NPY (32) in failing human ventricular myocardium is more pronounced in pressure-overloaded failing right ventricles removed from subjects with PPH, owing either to more severe muscle failure compared to IDC or to differences in pathophysiology.

Tissue dopamine and epinephrine levels were or tended to be higher in group $A$ ventricles than in either group B or C. For dopamine this may have been due to the limited use of therapeutic dopamine in the organ donor controls, although subjects not given dopamine still had tissue values that were $>200$ $\mathrm{ng} / \mathrm{g}$. Another potential explanation for increased dopamine levels in group $A$ is increased neuronal sympathetic activity in the "proximal" neuronal norepinephrine sympathetic pathway combined with a decreased enzymatic conversion of dopamine to norepinephrine, something that has been previously demon-

Table VI. Adenylate Cyclase Activities under "Standard" Conditions

\begin{tabular}{|c|c|c|c|c|c|c|c|c|}
\hline \multirow[b]{2}{*}{ Group } & \multirow[b]{2}{*}{ Chamber } & \multicolumn{7}{|c|}{ Adenylate cyclase activity } \\
\hline & & Basal & $\begin{array}{l}\text { Net } \\
\text { Iso }\end{array}$ & $\begin{array}{l}\text { Net } \\
\text { Zint }\end{array}$ & $\begin{array}{l}\text { Net } \\
\text { VIP }\end{array}$ & $\begin{array}{l}\text { Net } \\
\text { Hist }\end{array}$ & $\begin{array}{l}\text { Net } \\
\mathrm{NaF}\end{array}$ & $\begin{array}{l}\text { Net } \\
\text { Forsk }\end{array}$ \\
\hline & & \multicolumn{7}{|c|}{ pmol cAMP/min $\cdot m g$} \\
\hline \multicolumn{9}{|l|}{ A (Nonfailing, } \\
\hline \multirow[t]{2}{*}{$n=12)$} & LV & $11.4 \pm 1.0$ & $36.8 \pm 3.4$ & $13.8 \pm 2.7$ & $12.7 \pm 2.2$ & $5.0 \pm 1.0$ & $51.0 \pm 1.7$ & $303 \pm 23$ \\
\hline & $\mathbf{R V}$ & $12.3 \pm 1.3$ & $35.5 \pm 4.4$ & $12.8 \pm 2.4$ & $9.7 \pm 2.0$ & $8.0 \pm 1.6$ & $45.1 \pm 5.1$ & $268 \pm 19$ \\
\hline \multicolumn{9}{|c|}{ B (Biventricular } \\
\hline failure, & LV & $10.1 \pm 0.6$ & $28.5 \pm 2.0$ & $8.1 \pm 0.7^{*}$ & $12.4 \pm 1.3$ & $5.1 \pm 0.5$ & $45.5 \pm 3.3$ & $228 \pm 16$ \\
\hline$n=39)$ & $\mathbf{R V}$ & $8.4 \pm 0.8^{* \$}$ & $23.4 \pm 2.0^{* \$}$ & $6.8 \pm 0.8^{*}$ & $10.2 \pm 2.0$ & $4.2 \pm 0.8$ & $39.2 \pm 3.5^{8}$ & $197 \pm 16$ \\
\hline \multicolumn{9}{|l|}{ C (Isolated } \\
\hline RV failure, & LV & $11.9 \pm 1.0$ & $39.9 \pm 3.5^{\ddagger}$ & $12.6 \pm 1.1$ & $14.0 \pm 1.5$ & $5.6 \pm 1.3$ & $51.3 \pm 6.0$ & $276 \pm 33$ \\
\hline$n=12)$ & RV & $8.9 \pm 0.9^{\S}$ & $27.2 \pm 3.1^{8}$ & $8.8 \pm 1.4^{8}$ & $12.5 \pm 1.7$ & $5.3 \pm 1.3$ & $46.5 \pm 5.6$ & $200 \pm 23^{8}$ \\
\hline
\end{tabular}

Values are given \pm SEM. Abbreviations: Iso, isoproterenol; Zint, zinterol; Hist, histamine; Forsk, forskolin; and as in Table II. ${ }^{*} P<0.05$ vs. respective chamber in $\mathrm{A}$. ${ }^{\ddagger} P<0.05$ vs. respective chamber in $\mathrm{B}$. $P<0.05 \mathrm{vs} \mathrm{LV}$. 
Table VII. Adenylate Cyclase Activities in the Absence of Added Guanine Nucleotide and in the Presence of $10^{-6} M$ Propranolol ( $\mathrm{gpp}(\mathrm{NH}) \mathrm{p}$ Condition) or with the Above Minus $\mathrm{Mg}^{+2}\left(\mathrm{Mn}^{2+}\right.$ Condition)

\begin{tabular}{|c|c|c|c|c|c|c|}
\hline \multirow[b]{3}{*}{ Group } & \multirow[b]{3}{*}{ Chamber } & \multicolumn{5}{|c|}{ Adenylate cyclase activity } \\
\hline & & \multicolumn{3}{|c|}{ Gpp(NH)p condition } & \multicolumn{2}{|c|}{$\mathrm{Mn}^{2+}$ condition } \\
\hline & & Basal & $\begin{array}{l}\text { Gpp(NH)p } \\
\left(10^{-4} \mathrm{M}\right)\end{array}$ & $\begin{array}{c}\mathrm{NaF} \\
\left(10^{-2} \mathrm{M}\right)\end{array}$ & Basal & $\begin{array}{c}\mathrm{Mn}^{2+} \\
\left(10^{-2} \mathrm{M}\right)\end{array}$ \\
\hline & & \multicolumn{5}{|c|}{ pmol cAMP/min $\cdot \mathrm{mg}$} \\
\hline \multicolumn{7}{|l|}{ A (Nonfailing, } \\
\hline \multirow[t]{2}{*}{$n=8)$} & LV & $6.2 \pm 0.7$ & $14.2 \pm 2.9$ & $52.4 \pm 6.3$ & $0.90 \pm .21$ & $49.8 \pm 12.8$ \\
\hline & RV & $6.5 \pm 1.2$ & $11.4 \pm 3.0^{\S}$ & $43.8 \pm 4.3$ & $2.00 \pm .54$ & $65.1 \pm 8.3$ \\
\hline \multicolumn{7}{|c|}{ B (Biventricular } \\
\hline \multirow[t]{2}{*}{$n=32)$} & LV & $6.6 \pm 0.4$ & $8.9 \pm 0.7^{*}$ & $47.9 \pm 2.6$ & $1.32 \pm .15$ & $44.1 \pm 4.0$ \\
\hline & RV & $6.0 \pm 0.4$ & $9.3 \pm 0.6$ & $43.7 \pm 3.6$ & $1.15 \pm .31$ & $37.5 \pm 3.0^{*}$ \\
\hline \multicolumn{7}{|l|}{$\mathrm{C}$ (Isolated } \\
\hline RV failure, & LV & $9.4 \pm 1.4$ & $11.8 \pm 1.5$ & $56.1 \pm 6.6$ & $1.36 \pm .27$ & $40.4 \pm 7.7$ \\
\hline$n=6)$ & $\mathbf{R V}$ & $5.5 \pm 0.9^{\S}$ & $8.1 \pm 1.6^{8}$ & $38.0 \pm 4.3^{\S}$ & $0.68 \pm .09^{\S}$ & $23.6 \pm 4.2^{* \neq 5}$ \\
\hline
\end{tabular}

Values are given \pm SEM. ${ }^{*} P<0.05$ vs. respective chamber in A. ${ }^{\ddagger} P<0.05$ vs. respective chamber in $\mathrm{B} .{ }^{\S} P<0.05$ vs. LV.

strated in conditions of high adrenergic drive (33). For epinephrine the increase in group A ventricles was probably due to the markedly increased circulating levels known to occur in brain injury (34), with circulating epinephrine being taken up by the cardiac neuronal uptake system (35). The decrease in epinephrine levels in right vs. left ventricles of PPH hearts was probably due to the decreased catecholamine uptake that characterizes heart failure (18).

$\beta$-Agonist-mediated functional responses were reduced in PPH right ventricles. Muscle contraction, which is mediated by receptor subtypes in direct relation to their relative densities (11), was markedly reduced in PPH right ventricles relative to nonfailing right ventricular controls. The degree of reduction was by $58 \%$, which is in good agreement with the reduction in total $\beta\left(\beta_{1}+\beta_{2}\right)$ receptor density of $59 \%$ when compared to nonfailing right ventricles. Adenylate cyclase responsiveness to the nonselective $\beta$ agonist isoproterenol and the selective $\beta_{2}$ agonist zinterol was also reduced in PPH right ventricles, but to a lesser extent; in fact, for isoproterenol only the direct comparison to values in PPH left ventricles yielded a significant reduction. In human ventricular myocardium, adenylate cyclase re-

Table VIII. Muscle Bath Responses of Isolated Right Ventricular Trabeculae

\begin{tabular}{lcc}
\hline \multicolumn{1}{c}{ Group } & Isoproterenol & Calcium \\
\hline & & $m g$ \\
& & \\
A (Nonfailing, $n=19)$ & $1,966 \pm 348$ & $1,319 \pm 278$ \\
B (Biventricular failure, \\
$\quad \begin{array}{l}n=79) \\
\text { C (Isolated RV failure, } \\
n=17)\end{array}$ & $1,294 \pm 102^{*}$ & $1,180 \pm 93$ \\
& $825 \pm 103^{*}$ & $1,061 \pm 233$
\end{tabular}

Values are maximum net increase in tension $\pm \operatorname{SEM}(n$ refers to number of trabeculae).

${ }^{*} P<0.05$ vs. A. sponsiveness to isoproterenol is mediated primarily by $\beta_{2}$ receptors (12), which were not significantly decreased in PPH right ventricles relative to $\mathrm{PPH}$ left ventricle or nonfailing right ventricles. The decrease in zinterol responsiveness reflects exclusively the status of $\beta_{2}$ receptors (12), which were therefore mildly uncoupled from adenylate cyclase stimulation in PPH right ventricles and IDC left or right ventricles.

Numerous measurements were not decreased in failing PPH right vs. nonfailing left ventricles. They included creatine kinase levels, $\alpha_{1}$ receptor density, the percentage of the $\beta$ adrenergic receptors in a high-affinity agonist binding, overall agonist affinity as judged from isoproterenol competition curve position $\left(K_{\mathrm{I}}\right)$, and VIP, histamine, and fluoride-stimulated adenylate cyclase activities under standard assay conditions. With the exception of $\beta$ receptor agonist affinity, all these "nondifferences" have been previously reported for failing vs. nonfailing left ventricular myocardium $(22,26,36,37)$. These observations also argue for the preservation of cellular integrity of severely failing right ventricular myocardium removed from subjects with PPH, and against differences in membrane yield as the explanation for the decreases in adrenergic neuroeffector parameters.

In addition to the reduction in isoproterenol and zinterol stimulation of adenylate cyclase in PPH right ventricles measured under standard assay conditions, basal activity and forskolin stimulation were also reduced relative to PPH left ventricles. In addition, in the absence of added guanine nucleotides stimulation of adenylate cyclase by $\mathrm{NaF}$ and $\mathrm{Gpp}(\mathrm{NH}) \mathrm{p}$ was reduced in PPH right ventricles relative to paired left ventricles, despite stimulation by $\mathrm{NaF}$ not being reduced in PPH right ventricles when the assays were performed under standard conditions that included the addition of GTP and $\mathrm{Mg}^{2+}$. Similarly, with the $\mathrm{Mn}^{2+}$ condition (no added guanine nucleotides or $\mathrm{Mg}^{2+}$, addition of $10^{-6} \mathrm{M}$ propranolol) $\mathrm{Mn}^{2+}$ stimulation in PPH right ventricles was decreased relative to nonfailing right ventricles in group $A$. These data suggest that $P P H$ failing right ventricle exhibits a chamber-specific abnormality of the adenylate cyclase catalytic subunit $(C)$ which leads to a reduction in 
activity when $\mathrm{G}_{\mathrm{s}}$ is "activated" by $\mathrm{NaF}(38)$ or $\mathrm{C}$ is stimulated by $\mathrm{Mn}^{2+}(39)$. However, when GTP and $\mathrm{Mg}^{2+}$ are added to the reconstituted, standard adenylate cyclase assay condition the response of $\mathrm{PPH}$ right ventricular preparations to certain agonists (VIP, histamine, and NaF) is normal, suggesting that the catalytic subunit defect can be overcome by the addition of moderate amounts of guanine nucleotides and $\mathrm{Mg}^{2+}$.

Right ventricles from IDC subjects also exhibited a decrease in $\mathrm{Mn}^{2+}$ stimulation, relative to group A right ventricles. Additionally, under standard conditions group B right ventricles exhibited decreased basal activity, NaF stimulation, and nearly exhibited decreased forskolin stimulation relative to paired IDC left ventricles. IDC left ventricles did not exhibit the $\mathrm{Mn}^{2+}$ abnormality, suggesting that this and the other aforementioned decreases in adenylate cyclase activity were present in IDC right ventricles as a result of a mild catalytic subunit abnormality caused by the moderate right-sided pressure overload present in this group.

We $(13,40)$ and others $(41,42)$ have previously described a decrease in responsiveness to the nonhydrolyzable guanine nucleotide Gpp(NH)p in failing ventricles in both IDC and ischemic dilated cardiomyopathy, an abnormality that appears to be due to increased activity of the inhibitory $G$ protein, $G_{i}(40$, $43,44)$. In the current study the IDC left ventricles exhibited a level of $\mathrm{Gpp}(\mathrm{NH}) \mathrm{p}$ stimulation that was $63 \%$ of control values in group A left ventricles, similar in degree to previously described $(13,40)$ reductions. However, values for $\mathrm{Gpp}(\mathrm{NH}) \mathrm{p}$ stimulation in group $\mathrm{B}$ and $\mathrm{C}$ right ventricles were reduced by statistically insignificant amounts of $18 \%$ and $29 \%$, respectively. Given that $\mathrm{Mn}^{2+}$ stimulation and basal activity values in both groups $B$ and $C$ right ventricles supported the existence of a catalytic subunit abnormality, the data do not support a separate $G$ protein-related defect in pressure overloaded IDC or PPH failing right ventricles.

Both groups $B$ and $C$ isolated right ventricular preparations exhibited a reduced contractile response to isoproterenol. Although by ANOVA the decrease in isoproterenol-mediated contractile response in right ventricular trabeculae was not statistically different in IDC (by 33\%) vs. PPH (by 58\%), in view of the similar degree of $\beta$-receptor down-regulation in these two types of heart failure (by respective amounts of 53\% and 59\% in IDC and PPH right ventricles), it is possible that the greater degree of catalytic subunit abnormality in PPH right ventricles led to some additional compromise in $\beta$-receptor-mediated responsiveness. The adenylate cyclase catalytic subunit defect that appeared to be present in direct relation to the degree of pressure overload in failing human right ventricles is similar to the abnormality in adenylate cyclase that has been previously described in pressure overloaded failing left ventricles in guinea pigs (45) and dogs (46). The agonist affinity status of $\beta$-adrenergic receptors in failing human ventricular myocardium has not been previously reported, and the finding of no change in failing myocardium is in disagreement with work in at least one heart failure animal model (47). In this banded aorta, pressureoverload model $\beta$-receptor agonist affinity decreases (47) in conjunction with a decrease in the amount/activities of $G_{s}(48)$ and the adenylate cyclase catalytic subunit (46). The differences between this model and human myocardial failure are likely due to both species and model differences.

The selective, chamber-specific decrease in $\beta_{1}$ receptor density and adrenergic neurotransmitters suggests that these two phenomena are related. The $\beta_{1}$ receptor has a higher affinity for norepinephrine than does the $\beta_{2}$ receptor $(26,49)$, and occupancy of $\beta_{1}$ receptors by the increased amount of cardiac-derived norepinephrine present in the failing human heart may be one cause of $\beta_{1}$-receptor down-regulation (50). In heart failure tissue depletion of norepinephrine (14-16) occurs in the face of increased myocardial norepinephrine production (17, 18,20 ), as relative preservation of norepinephrine release (20) coupled with decreased reuptake (18-20) ultimately depletes tissue stores (14-16). Norepinephrine depletion is therefore a marker of increased adrenergic neuronal function, and consequently it would be expected that $\beta_{1}$-receptor down-regulation and adrenergic neurotransmitter depletion would co-vary and be confined to failing chambers.

In this study the neuroeffector abnormalities are similar to previously reported data, including reduction in tissue norepinephrine $(15,16)$, down-regulation of total $\beta$ - and $\beta_{1}$-adrenergic receptors $(11,12,22)$, decreased $\beta$ agonist responsiveness of adenylate cyclase $(12,22)$ decreased inotropic responsiveness of isolated tissue to isoproterenol $(11,22)$, and decreased responsiveness of adenylate cyclase to $\mathrm{Gpp}(\mathrm{NH}) \mathrm{p}(40-42)$. This study demonstrates that the abnormalities previously described in smaller sample sizes of left and right ventricular myocardium are present to a similar degree when larger numbers of endstage IDC ventricles are examined.

Although studies in animal models of heart failure have not consistently demonstrated $\beta$-receptor down-regulation, a recent study in pulmonary artery-banded dogs reported selective right ventricular $\beta$-receptor down-regulation (51) that was similar to that reported in the current study. This volume/pressure overload model of isolated right ventricular failure also exhibits selective norepinephrine depletion and selective loss of norepinephrine uptake (52). However, this canine model differs from human hearts removed from subjects with PPH by exhibiting a "postreceptor" defect in the adenylate cyclase complex, with responses to forskolin, $\mathrm{Gpp}(\mathrm{NH}) \mathrm{p}$, and isoproterenol being decreased in both ventricles (51). In contrast, in the current study nonfailing human left ventricles removed from subjects with PPH exhibited normal (not different from organ donor controls) adenylate cyclase responses to all agonists in PPH left ventricles. In view of the fact that our PPH subjects had severe heart failure, it is perhaps surprising that hormonal influences such as elevations in circulating catecholamines did not produce evidence for a postreceptor, or heterologous, desensitization in PPH left ventricles. One potential explanation for this is that the organ donor controls had already developed mild desensitization, by virtue of the increased sympathetic drive present in brain injured subjects (34). Indirect evidence for increased sympathetic activity was in fact present in group $\mathrm{A}$, in the form of increased tissue epinephrine levels that presumably reflected uptake of increased circulating levels. It is important to realize that no type of control human myocardium will be completely "normal" in explanted material inasmuch as some sort of process with an invariable systemic component had to be present in order for the tissue to become available. This is why the changes described in this and our previous papers dealing with abnormal $\beta$-adrenergic neuroeffector mechanisms in explanted human heart are interpreted as changes in failing vs. nonfailing heart, as opposed to failing vs. normal. It is in fact quite likely that the degree of change in $\beta$-adrenergic neuroeffector mechanisms in the failing human heart is underesti- 
mated by a comparison to controls which may already have some degree of abnormality.

A general observation about PPH failing right ventricles is that the described adrenergic neuroeffector abnormalities were more pronounced than in IDC failing right or left ventricles. Relative to values in IDC right ventricles, PPH right ventricular values were $12 \%$ lower for $\beta_{1}$ receptor density, $70 \%$ lower for norepinephrine level, $38 \%$ lower for NPY level, and 36\% lower for isoproterenol stimulation of muscle contraction. The general explanation for these quantitative differences between these two types of heart muscle disease is either more severe myocardial dysfunction in the markedly afterloaded PPH right ventricle, or "model" differences between these two types of heart muscle disease.

With the evidence presented in the current investigation that pressure-overloaded, failing human ventricular myocardium exhibits a defect in the adenylate cyclase catalytic subunit a total of six abnormalities of the $\beta$-adrenergic neuroeffector system have now been described in the ventricular free walls of various types of failing human ventricular myocardium that has not been exposed to pharmacologic agents known to perturb the $\beta$ receptor pathway. As outlined in Table IX, these are (a) depletion of adrenergic neurotransmitters, found in all types of failing heart examined to date $(14-16,35),(b)$ downregulation of $\beta_{1}$-adrenergic receptors, which has been found in all types of failing human heart (11-13, 22, 53-55), (c) uncoupling of $\beta_{2}$-adrenergic receptors, found in all types of failing human heart examined to date $(12,13),(d)$ increased $G_{i}$ activity, found in the left ventricles of idiopathic and both ventricles of ischemic dilated cardiomyopathy $(12,13,39,43,44),(e)$ uncoupling of $\beta_{1}$-adrenergic receptors, found in ischemic dilated cardiomyopathy (13); $(f)$ decreased adenylate cyclase catalytic subunit activity, found in pressure overloaded, failing right ventricles.

Table IX. Summary of Abnormalities in the $\beta$-Adrenergic Neuroeffector Systems in Various Kinds of Dilated Cardiomyopathy

\begin{tabular}{lccc}
\hline \multicolumn{1}{c}{ Abnormality } & $\begin{array}{c}\text { IDC } \\
(\mathrm{LV}, \mathrm{RV})^{*}\end{array}$ & $\begin{array}{c}\text { ISCDC } \\
(\mathrm{LV}, \mathrm{RV})^{\ddagger}\end{array}$ & $\begin{array}{c}\text { PPH } \\
(\mathrm{RV})^{s}\end{array}$ \\
\hline $\begin{array}{l}\text { Neurotransmitter depletion } \\
\begin{array}{l}\text { Down-regulation of } \beta_{1}- \\
\text { adrenergic receptors }\end{array}\end{array}$ & ++ & ++ & +++ \\
$\begin{array}{l}\text { Uncoupling of } \beta_{2} \text {-adrenergic } \\
\text { receptors }\end{array}$ & ++ & + & +++ \\
$\begin{array}{l}\text { Increased activity of } \mathrm{G}_{\mathrm{i}} / \\
\text { decreased Gpp(NH) stimulation }\end{array}$ & $+(\mathrm{LV}$ only) & + & - \\
$\begin{array}{l}\text { Uncoupling of } \beta_{1} \text {-adrenergic } \\
\text { receptors }\end{array}$ & - & +++ & - \\
$\begin{array}{l}\text { Decreased adenylate cyclase } \\
\text { catalytic subunit activity }\end{array}$ & $+(\mathrm{RV}$ only) & - & ++ \\
\hline
\end{tabular}

Degree of abnormality classified as:,- no abnormality; $+=$ mild; ++ $=$ moderate $+++=$ marked abnormality.

* Idiopathic dilated cardiomyopathy (11-13, 22, 40-44, 54).

₹ Ischemic dilated cardiomyopathy (13).

${ }^{8}$ Primary pulmonary hypertension (pressure-overloaded right ventricle).
Neurotransmitter depletion, down-regulation of $\beta_{1}$ receptors uncoupling of $\beta_{2}$ receptors and perhaps the increase in $G_{i}$ activity may all be attributed to the increased adrenergic drive that characterizes the failing human heart $(9,56)$. In contrast, uncoupling of $\beta_{1}$ receptors may be the result of local ischemia $(13,57)$, whereas decreased adenylate cyclase catalytic activity may be secondary to load-dependent tissue injury $(45,46)$. These changes involving the powerful contractility-regulating receptor-G protein-adenylate cyclase pathway in the human heart indicate that this system has multiple potential regulatory sites, and the diversity of changes in different types of heart muscle disease illustrate the "model dependency" $(9,56)$ of the system.

The most important observation from this study is that the profound adrenergic abnormalities that occur in failing human heart muscle are under local control, with systemic or humoral mechanisms playing no obvious role in their development. Since in PPH subjects systemic plasma norepinephrine levels were increased but $\beta$-adrenergic receptors and neurotransmitter levels were not altered in nonfailing left ventricles, elevated circulating norepinephrine could not have caused the abnormalities present in PPH right ventricles. Additionally, Vatner et al. (58) have recently shown that normally functioning canine heart exposed to elevated circulating norepinephrine levels develops up-regulation of uncoupled myocardial $\beta_{1}$-adrenergic receptors and a decrease in $G_{s}$, along with a shift of the agonist binding state from high to low affinity. None of these changes were present in nonfailing left or failing right ventricles of PPH hearts. It is therefore likely that local, myocardial mechanisms are responsible for the changes that occur in the $\beta$ adrenergic neuroeffector mechanism in failing human ventricular myocardium.

From the standpoint of adrenergic nerve function, this means that the central nervous system must have a way of sensing that a region of heart muscle is failing, perhaps via an afferent reflex originating in failing regions that leads to increased sympathetic nerve traffic directed back to that region, or that local processes can influence neurotransmitter pharmacodynamics, such as by decreasing norepinephrine reuptake. Since the adrenergic cotransmitter NPY has no known reuptake mechanism, increased regional NPY release and/or adrenergic neuronal attrition presumably occurs in failing ventricular myocardium. Similarly, the factors that account for $\beta_{1}$-receptor down-regulation are also locally activated in failing heart muscle. These factors may well be linked to adrenergic nerve traffic, either directly through norepinephrine exposure or indirectly through cotransmission of other substances.

In summary, the adrenergic abnormalities previously described in the failing human heart occur only in chambers with abnormal function, and are not present in adjacent nonfailing chambers. Thus despite the widespread activation of hormonal mechanisms that accompanies the clinical syndrome of heart failure, the regulatory processes that account for adrenergic neuroeffector abnormalities in the failing human heart are under local rather than systemic control.

\section{Acknowledgments}

The authors are grateful to Rebecca Burns for assistance in manuscript preparation, and to Mark Thorpe for his technical assistance. 


\section{References}

1. Thomas, J. A., and B. H. Marks. 1978. Plasma norepinephrine in congestive heart failure. Am. J. Cardiol. 41:233-243.

2. Cohn, J. N., T. B. Levine, M. T. Olivari, V. Garberg, D. Lura, G. S. Francis, A. B. Simon, and T. Rector. 1984. Plasma norepinephrine as a guide to prognosis in patients with chronic congestive heart failure. N. Engl. J. Med. 311:819-823.

3. Hasking, G. J., M. D. Esler, G. L. Jennings, D. Burton, and P. I. Korner 1986. Norepinephrine spillover to plasma in patients with congestive heart failure: evidence of increased overall and cardiorenal sympathetic nervous activity. Circulation. 73:615-621.

4. Dzau, V. J., W. S. Collucci, N. K. Hollenberg, and G. H. Williams. 1981. Relation of the renin-angiotensin-aldosterone system to clinical state in congestive heart failure. Circulation. 63:645-651.

5. Cohn, J. N., T. B. Levine, G. S. Francis, and S. Goldsmith. 1981. Neurohumoral control mechanisms in congestive heart failure. Am. Heart. J. 102:509514.

6. Cody, R. J., S. A. Atlas, J. H. Laragh, S. H. Kubo, A. B. Covit, K. S. Ryman, A. Shaknovitch, K. Pondolfino, M. Clark, M. J. F. Camargo, et al. 1986. Atria natriuretic factor in normal subjects and heart failure patients: plasma levels and renal, hormonal, and hemodynamic responses to peptide infusion. J. Clin. Invest. 78:1362-1374

7. Dzau, V. J., M. Packer, L. S. Lilly, S. L. Swartz, N. K. Hollenberg, and G. H. Williams. 1984. Prostaglandins in severe heart failure: relation to activation of the renin-angiotensin system and hyponatremia. $N$. Engl. J. Med. 310:347352.

8. Packer, M. 1988. Neurohormonal interactions and adaptations in congestive heart failure. Circulation. 77:721-730.

9. Feldman, A. M., and M. R. Bristow. 1990. Adrenergic neuroeffector mechanisms in the failing human heart. In Heart Disease: Clinical Update. Volume 9. E Braunwald, editor. W. B. Saunders Co., Philadelphia, PA. p. 206-216.

10. The Consensus Trial Study Group. 1987. Effects of enalapril on mortality in severe congestive heart failure. $N$. Engl. J. Med. 316:1429-1435.

11. Bristow, M. R., R. Ginsburg, M. Fowler, W. Minobe, R. Rasmussen, P. Zera, R. Menlove, P. Shah, and E. Stinson. 1986. $\beta_{1}$ and $\beta_{2}$-adrenergic receptor subpopulations in normal and failing human ventricular myocardium: coupling of both receptor subtypes to muscle contraction and selective $\beta_{1}$ receptor downregulation in heart failure. Circ. Res. 59:297-309.

12. Bristow, M. R., R. E. Hershberger, J. D. Port, and R. Rasmussen. 1989. $\beta_{1}$ and $\beta_{2}$ adrenergic receptor-mediated adenylate cyclase stimulation in nonfailing and failing human ventricular myocardium. Mol. Pharmacol. 35:295-303.

13. Bristow, M. R., F. L. Anderson, J. D. Port, L. Skerl, R. E. Hershberger, P. Larrabee, J. B. O'Connell, D. G. Renlund, K. Volkman, J. Murray, et al. 1991. Differences in $\beta$-adrenergic neuroeffector mechanisms in ischemic vs. idiopathic dilated cardiomyopathy. Circulation. 84:1024-1039.

14. Chidsey, C. A., E. Braunwald, and A. G. Morrow. 1965. Catecholamine excretion and cardiac stores of norepinephrine in congestive heart failure. Am. J. Med. 39:442-451.

15. Pierpont, G. L., G. S. Francis, E. G. DeMaster, M. T. Olivari, W. S. Ring, I. F. Goldenberg, S. Reynolds, and J. N. Cohn. 1987. Heterogeneous myocardial catecholamine concentrations in patients with congestive heart failure. Am. J. Cardiol. 60:316-321.

16. Port, J. D., E. M. Gilbert, P. Larrabee, P. Mealey, K. Volkman, R. Ginsburg, R. E. Hershberger, and M. R. Bristow. 1990. Neurotransmitter depletion compromises the ability of indirect acting amines to provide inotropic support in the failing human heart. Circulation. 81:929-938.

17. Swedberg, K., C. Viquerat, J. L. Rouleau, M. Roizen, B. Atherton, W. W. Parmley, and K. Chatterjee. 1984. Comparison of myocardial catecholamine balance in chronic congestive heart failure and in angina pectoris without failure. Am. J. Cardiol. 54:783-786.

18. Rose, C. P., J. H. Burgess, and D. Cousineau. 1983. Reduced aortocoronary sinus extraction of epinephrine in patients with left ventricular failure secondary to long-term pressure or volume overload. Circulation. 68:241-244.18.

19. Petch, M. C., and W. G. Nayler. 1979. Uptake of catecholamines by human cardiac muscle in vitro. Br. Heart J. 41:336-339.

20. Sandoval, A. B., E. M. Gilbert, C. P. Rose, and M. R. Bristow. 1989. Cardiac norepinephrine uptake and release is decreased in dilated cardiomyopathy. Circulation. 80(Suppl. IV):393.

21. Gilbert, E. M., S. K. Krueger, J. L. Murray, D. G. Renlund, J. B. O'Connell, W. A. Gay, and M. R. Bristow. 1988. Echocardiographic evaluation of potential cardiac transplant donors. J. Thorac. Cardovasc. Surg. 95:1003-1007.

22. Bristow, M. R., R. Ginsburg, W. Minobe, R. S. Cubicciotti, W. S. Sageman, K. Lurie, M. R. Billingham, D. C. Harrison, and E. B. Stinson. 1982 Decreased catecholamine sensitivity and adrenergic-receptor density in failing human hearts. $N$. Engl. J. Med. 307:205-211.

23. Fowler, M. B., J. A. Laser, G. L. Hopkins, W. Minobe, and M. R. Bristow. 1986. Assessment of the $\beta$-adrenergic receptor pathway in the intact failing hu- man heart: progressive receptor down-regulation and subsensitivity to agonist response. Circulation. 74:1290-1302.

24. Bristow, M. R., R. Ginsburg, A. Strosberg, W. Montgomery, and W. Minobe. 1984. Pharmacology and inotropic potential of forskolin in the human heart. J. Clin. Invest. 74:212-223.

25. Dooley, E. J., H. Bittiger, and N. C. Reymann. 1986. CGP 20712A: a

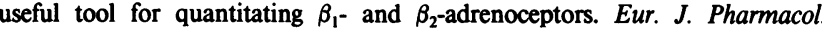
130:137-139.

26. Bristow, M. R., W. Minobe, R. Rasmussen, R. E. Hershberger, and B. B. Hoffman. 1988. Alpha ${ }_{1}$ adrenergic receptors in the nonfailing and failing human heart. J. Pharmacol. Exp. Ther. 247:1039-1045.

27. Salomon, Y., C. Londos, and M. Rodbell. 1974. A highly sensitive adenylate cyclase assay. Anal. Biochem. 58:541-548.

28. Peterson, G. L. 1977. A simplification of the protein assay method of Lowry et al. which is more generally applicable. Anal. Biochem. 83:346-356.

29. Bristow, M. R., W. Minobe, R. Rasmussen, R. Ginsburg, M. Fowler, and P. Larrabee. 1985. Chamber-specific adrenergic abnormalities in isolated right ventricular failure in the human heart (abst.). Circulation. 72(Suppl. III): 183.

30. Port, J. D., L. Skerl, J. B. O'Connell, D. G. Renlund, P. Larrabee, and M. R. Bristow. 1990. Increased expression of $\beta_{2}$-adrenergic receptors in surgically denervated, previously transplanted human ventricular myocardium. J. Am. Col Cardiol. 15:84A. (Abstr.)

31. Linden, J., A. Patel, A. M. Spanier, and W. B. Weglicki. 1984. Rapid agonist-induced decrease of ${ }^{125} \mathrm{I}$-pindolol binding to $\beta$-adrenergic receptors. $J$. Biol. Chem. 259:15115-15122.

32. Anderson, F. L., J. D. Port, B. B. Reid, and P. Larrabee. Hanson, G. 1991. Myocardial catecholamine and neuropeptide $Y$ depletion in the failing ventricles of patients with idiopathic dilated cardiomyopathy: correlation with beta adrenergic receptor down-regulation. Circulation. In press.

33. Sole, M. J., C. J. Helke, and D. M. Jacobowitz. 1982. Increased dopamine in the failing hamster heart: transvesicular transport of dopamine limits the rate of norepinephrine synthesis. Am. J. Cardiol. 49:1682-1690.

34. Hamill, R. W., P. D. Woolf, J. V. McDonald, L. A. Lee, and M. Kelly. 1987. Catecholamines predict outcome in traumatic brain injury. Ann. Neurol. 21:438-443.

35. Iversen, L. L. 1975. Uptake processes for biogenic amines. In Handbook of Psycopharmacology. Volume 3. L. L. Iverson, S. D. Iverson, and S. H. Snyder, editors. Plenum Press, New York. 381-442.

36. Bristow, M. R., R. Cubicciotti, R. Ginsburg, E. G. Stinson, and C. Johnson. 1982. Histamine-mediated adenylate cyclase stimulation in human myocardium. Mol. Pharmacol. 21:671-679.

37. Hershberger, R. E., F. L. Anderson, and M. R. Bristow. 1988. The vasoactive intestinal peptide receptor in failing and nonfailing human ventricular myocardium: supersensitivity of failing heart due to increased response from decreased receptor density. J. Am. Col. Cardiol. 11:1A. (Abstr.)

38. Gilman, A. G. 1987. G proteins: transducers of receptor-generated signals. Annu. Rev. Biochem. 56:615-648.

39. Strittmatter, S., and E. J. Neer. 1980. Properties of the separated catalytic and regulatory units of brain adenylate cyclase. Proc. Natl. Acad. Sci. USA. 77:6344-6348.

40. Feldman, A. M., A. E. Cates, W. B. Veazey, R. E. Hershberger, M. R Bristow, K. L. Baughman, W. A. Baumgartner, and C. Van Dop. 1988. Increase of the 40,000 -mol wt pertussis toxin substrate (G protein) in the failing human heart. J. Clin. Invest. 82:189-197.

41. Denniss, A. R., J. D. Marsh, R. J. Quigg, J. B. Gordon, and W. S. Colucci. 1989. $\beta$-adrenergic receptor number and adenylate cyclase function in denervated transplanted and cardiomyopathic human hearts. Circulation. 79:10281034.

42. Karliner, J. S., and M. Scheinman. 1988. Adenylate cyclase activity coupled to the stimulatory guanine nucleotide binding protein in patients having electrophysiologic studies and either structurally normal hearts or idiopathic myocardial disease. Am. J. Cardiol. 62:1129-1130.

43. Neumann, J., W. Schmitz, H. Scholz, L. V. Meyerinck, V. Doring, and P. Kalmar. 1988. Increase in myocardial $\mathrm{G}_{\mathrm{i}}$-proteins in heart failure. Lancet. 2:936937.

44. Bohm, M., P. Gierschik, K. H. Jakobs, P. Schnabel, B. Kemkes, and E. Erdmann. 1989. Localization of a "postreceptor" defect in human dilated cardiomyopathy. Am. J. Cardiol. 64:812-814.

45. Sobel, B. E., P. D. Henry, A. Robison, C. Bloor, and J. Ross. 1969 Depressed adenyl cyclase activity in the failing guinea pig heart. Circ. Res. 24:507-512.

46. Chen, L., D. E. Vatner, S. F. Vatner, L. Hittinger, and C. J. Homcy. 1991. Decreased $G_{\omega}$ mRNA levels accompany the fall in $G_{s}$ and adenylyl cyclase activities in compensated left ventricular hypertrophy: in heart failure, only the impairment in adenylyl cyclase activation progresses. J. Clin. Invest. 87:293-298.

47. Vatner, D. E., C. J. Homcy, S. P. Sit, W. T. Manders, and S. F. Vatner 1984. Effects of pressure overload, left ventricular hypertrophy on $\beta$-adrenergic receptors, and responsiveness to catecholamines. J. Clin. Invest. 73:1473-1482. 
48. Longabaugh, J. P., D. E. Vatner, S. F. Vatner, and C. J. Homcy. 1988. Decreased stimulatory guanosine triphosphate binding protein in dogs with pressure-overload left ventricular failure. J. Clin. Invest. 81:420-424.

49. Lands, A. M., A. Arnold, J. P. McAuliff, G. P. Luduena, and T. G. Brown. 1967. Differentiation of receptor systems activated by sympathomimetic amines. Nature (Lond.). 214:597-598.

50. Bristow, M. R., A. B. Sandoval, E. M. Gilbert, T. Deisher, W. Minobe, and R. Rasmussen. 1988. Myocardial $\alpha$-and $\beta$-adrenergic receptors in heart failure: Is cardiac-derived norepinephrine the regulatory signal? Eur. Heart J. 9:35-40.

51. Fan, T.-H. M., C.-S. Liang, S. Kawashima, and S. P. Banerjee. 1987 Alterations in cardiac $\beta$-adrenoceptor responsiveness and adenylate cyclase system by congestive heart failure in dogs. Eur. J. Pharmacol. 140:123-132.

52. Liang, C.-S., T.-H. M. Fan, J. T. Sullebarger, and S. Sakamoto. 1989. Decreased adrenergic neuronal uptake activity in experimental right heart failure. J. Clin. Invest. 84:1267-1275.

53. Bristow, M. R., J. A. Laser, W. Minobe, R. Ginsburg, M. B. Fowler, and R. Rasmussen. 1984. Selective down-regulation of $\beta_{1}$ adrenergic receptors in the failing human heart. Circulation. 70(Suppl. II):67. (Abstr.)

54. Brodde, O. E., S. Schuler, R. Kretsch, M. Brinkmann, H. G. Borst, R.
Hetzer, J. C. Reidemeister, H. Warnecke, and H.-R. Zerkowski. 1986. Regional distribution of $\beta$-adrenoceptors in the human heart: coexistence of functional $\beta_{1^{-}}$ and $\beta_{2}$-adrenoceptors in both atria and ventricles in severe congestive cardiomyopathy. J. Cardiovasc. Pharmacol. 8:1235-1242.

55. Brodde, O. E., H. R. Zerkowski, N. Doetsch, S. Motomura, M. Khamssi, and M. C. Michel. 1989. Myocardial beta-adrenoceptor changes in heart failure: concomitant reduction in beta ${ }_{1}$ - and beta $a_{2}$-adrenoceptor function related to the degree of heart failure in patients with mitral valve disease. J. Am. Col. Cardiol. 14:323-331.

56. Bristow, M. R., R. E. Hershberger, J. D. Port, A. Sandoval, R. Rasmussen A. E. Cates, and A. M. Feldman. 1990 $\beta$-adrenergic pathways in nonfailing and failing human ventricular myocardium. Circulation. 82:12-25.

57. Karliner, J. S., M. B. Stevens, N. Honbo, and J. I. E. Hoffman. 1989. Effects of acute ischemia in the dog on myocardial blood flow, beta receptors, and adenylate cyclase activity with and without chronic beta blockade. J. Clin. Invest. 83:474-481.

58. Vatner, D. E., S. F. Vatner, J. Nejima, N. Uemura, and E. E. Susanni. 1989. Chronic norepinephrine elicits desensitization by uncoupling the $\beta$-receptor. J. Clin. Invest. 84:1741-1748. 